\title{
Apparent richness and community composition of Bacteria and Archaea in geothermal springs
}

\author{
Konstantinos Ar. Kormas ${ }^{1, *}$, Hideyuki Tamaki ${ }^{2}$, Satoshi Hanada ${ }^{2}$, Yoichi Kamagata ${ }^{2,3}$ \\ ${ }^{1}$ Department of Ichthyology and Aquatic Environment, University of Thessaly, 38446 Nea Ionia, Greece \\ ${ }^{2}$ Institute for Biological Resources and Functions, National Institute of Advanced Industrial Science and Technology (AIST), \\ Central 6, Higashi 1-1-1, Tsukuba, Ibaraki 305-8566, Japan \\ ${ }^{3}$ Research Institute for Genome-based Biofactory, National Institute of Advanced Industrial Science and Technology (AIST), \\ 2-17-2-1, Tsukisamu-higashi, Toyohira-ku, Sapporo 062-8517, Japan
}

\begin{abstract}
The archaeal and bacterial 16S rRNA gene diversities of the Polihnitos $\left(89^{\circ} \mathrm{C}\right)$, Edipsos $\left(81.8^{\circ} \mathrm{C}\right)$, Thermopiles $\left(38.9^{\circ} \mathrm{C}\right)$, Eleftheres $\left(41.2^{\circ} \mathrm{C}\right)$ and Lagadas $\left(35.2^{\circ} \mathrm{C}\right)$ geothermal springs in Greece were investigated. The abundance of prokaryotic cells varied between $0.02 \times 10^{5}$ and $0.92 \times$ $10^{5}$ cells $\mathrm{ml}^{-1}$. A total of 227 archaeal and 501 bacterial clones were analysed, which were attributed to 85 and 121 operational taxonomic units (OTUs), respectively. Library clone coverage, based on Good's C estimator, was satisfactory (>75\%), except for the Archaea in Thermopiles $(\sim 40 \%)$ and Eleftheres ( $\sim 60 \%)$. Most of the archaeal phylotypes were related to sequences of yet-uncultivated microorganisms retrieved from terrestrial geothermal springs, deep-sea hydrothermal vents and the subsurface. A much higher number of bacterial phylotypes was related to cultivated microorganisms from similar environments. The thermophilic nature of most of the discovered phylotypes was also supported by their high $\mathrm{G}+\mathrm{C}$ content, which was positively correlated with the springs' temperatures. The springs showed different diversity patterns for Bacteria and Archaea, with Bacteria having higher diversity only in Polihnitos and Lagadas springs. The Shannon diversity index $H^{\prime}$ showed larger variation for Archaea (0.23 to 3.44) than for Bacteria (1.22 to 3.03) and was unrelated to the prevailing temperature, $\mathrm{pH}$, salinity and dissolved oxygen content. Archaeal and bacterial clone libraries respectively contained 50 to 94.1 and 68.8 to $96.2 \%$ rare phylotypes (i.e. those that appear only once or twice in the clone library), indicating the importance of rare phylotypes in shaping community diversity.
\end{abstract}

KEY WORDS: Bacteria $\cdot$ Archaea $\cdot 16 \mathrm{~S}$ rRNA $\cdot$ Geothermal springs $\cdot$ Greece

\section{INTRODUCTION}

Natural geothermal springs are widespread on the Earth's surface. Excluding deep-sea hot vents, the most accessible ones are terrestrial geothermal springs, solfataras and geothermally heated soils. Greece harbours many terrestrial and coastal sites where geothermal springs occur, with temperatures between $\sim 30$ and $90^{\circ} \mathrm{C}$, due to the geology of the country. Geothermal areas in the country are related to recent volcanic activity and active tectonics. Magmatic and volcanic processes, along with the high mountain chains and active fault systems, favour the rise of deep waters which are discharged at the surface as geothermal springs. The origin of the fluid movement results from a thermal gradient closely related to volcanic activity, leading to convection, for the majority of springs within areas of Tertiary basins in northern Greece and the Aegean island arc. These springs occur mainly in the post-orogenic basins of the northern Aegean and the Aegean island arc. In western Greece, where volcanic activity does not exist, the thermal gradient is due only to depth. The prokaryotic diversity of the shallow hydrothermal vents of Milos Island on the Aegean island arc has been previously studied (Sievert et al. 1999, 2000). Geothermal spring waters in islands 
and coastal areas are typical of marine solutions and result from the mixing of deep thermal reservoir water with meteoric water. In continental areas, thermal water rising from deep reservoirs is frequently localized in aquifers of neogene sediments such as conglomerates and sandstones, or may be mixed with karstic surface water. In general, the chemistry of Greek geothermal springs is due to the interaction of groundwater with silicic rocks bearing alkaline elements and some carbonates (mostly marbles), or with shallow aquifers and seawater, e.g. Thermopiles springs (Duriez et al. 2008). Geothermometric analysis, i.e. inferring temperature ranges from the occurring minerals in spring water, suggests that the mean temperatures of hot spring waters are between 149 and $187^{\circ} \mathrm{C}$. These temperatures are probably due to a normal gradient, since the depth of the post-orogenic basin of Greece is thought to be $>4000 \mathrm{~m}$ (Lambrakis \& Kallergis 2005).

Although the geochemical features of the majority of geothermal springs in Greece have been the focus of several studies (reviewed by Lambrakis \& Kallergis 2005), the available information on the microbiology of such springs is remarkably scarce. Except for the Milos Island shallow vents, where diverse archaeal and bacterial communities dictated by temperature and geochemical gradients have been revealed (Sievert et al. 1999, 2000), to our knowledge, only one study that focused on the isolation of thermophilic strains that are able to degrade crude oil originating from geothermal soils, sediments and waters on the volcanic island of Santorini exists (Meintanis et al. 2006).

It is well accepted that geothermal springs have sitespecific biological, physical and chemical diversities. In addition, solid relationships of the existing microorganisms with the prevailing geochemical parameters are usually difficult to unravel as the majority of the retrieved sequences are new or unknown, making understanding of the microbial ecophysiology a really challenging task. One way of overcoming this problem is to discover trends of microbial diversity in order to determine whether temperature, substrates, toxic compounds or viruses play key roles in shaping the microbial communities in geothermal springs. Patterns of bacterial diversity give us a better understanding of how bacteria are distributed spatially and temporally (van der Gast 2008), and geothermal springs are considered to be among the extreme environments of pristine quality. In geothermal springs, temporal changes are expected to be much lower than in other surface habitats (Staley \& Reysenbach 2002); thus, changes in bacterial diversity most probably depict changes dictated by spatial factors, like different origin depth and/or different available electron acceptors and donors for microbial metabolism. The aims of the present study were to investigate
(1) archaeal and bacterial diversities based on 16S rRNA gene phylogenetic relationships in the waters of 5 terrestrial geothermal springs from 4 different geothermal fields with temperatures ranging from $\sim 36$ to $89^{\circ} \mathrm{C}$, and (2) the pattern of microbial diversity in geothermal springs with a wide range of different physical and chemical characteristics.

\section{MATERIALS AND METHODS}

Sampling and prokaryotic cell abundance. Water was collected from the Polihnitos (Pol), Edipsos (Edi), Thermopiles (Thp), Eleftheres (Ele) and Lagadas (Lag) geothermal springs in Greece (Fig. 1) between January and May 2005. Water samples of $20 \mathrm{l}$ were collected in pre-sterilised carboys either from 20 to $30 \mathrm{~cm}$ below the surface in the case of pools (Pol, Thp, Lag, Ele) or by direct filling in the case of seeps (Edi). The samples were transferred immediately $(<12 \mathrm{~h})$ to the laboratory and filtered upon arrival. Water was filtered under low vacuum $(<150 \mathrm{~mm} \mathrm{Hg}$ ) through polycarbonate filters of $0.2 \mu \mathrm{m}$ pore size and the filters were kept at $-80^{\circ} \mathrm{C}$ until further analysis. In situ measurements of temperature, $\mathrm{pH}$, salinity and dissolved oxygen content were conducted using probes (YSI). Bacterial counts were measured using epifluorescence microscopy as described by Turley (1993).

PCR amplification and cloning. DNA was extracted using a soil DNA isolation kit (UltraClean, MoBio Laboratories) according to the manufacturer's protocol after slicing the filters with a sterile scalpel. For each 16S rRNA PCR amplification, $0.5 \mu \mathrm{l}$ of the DNA template ( 90 to $160 \mathrm{ng} \mathrm{\mu l}^{-1}$ ) was used. To decrease PCR bias related to high numbers of cycles and minimize differences in clone library representation between rare and abundant phylotypes, PCR cycle optimization was performed, i.e. each PCR was performed at the minimum number of cycles where a positive PCR signal occurred. For all samples, a mixture of archaeal and bacterial universal primers was used in order to cover possible mismatches (Table 1).

Each $50 \mu \mathrm{l}$ PCR reaction consisted of a 9 min prePCR hold at $95^{\circ} \mathrm{C}$, followed by $x$ number of cycles as determined by cycle optimisation (Table 1) consisting of a 1 min denaturation step at $95^{\circ} \mathrm{C}$, a 1 min annealing step at $50^{\circ} \mathrm{C}$, a 2 min elongation step at $72^{\circ} \mathrm{C}$, and a final 10 min finishing step at $72^{\circ} \mathrm{C}$ at the end of $x$ number of cycles. All PCR ingredients were prepared with twice-autoclaved ultra pure water, using Ampli Taq Gold polymerase (Applied Biosystems). The PCR products were checked on a $1.2 \%$ agarose gel at $100 \mathrm{~V}$ for $35 \mathrm{~min}$, and were purified using a purification kit (Montage, Millipore). The purified PCR products were cloned with a T-vector kit (pT7 Blue, Novagen). The 


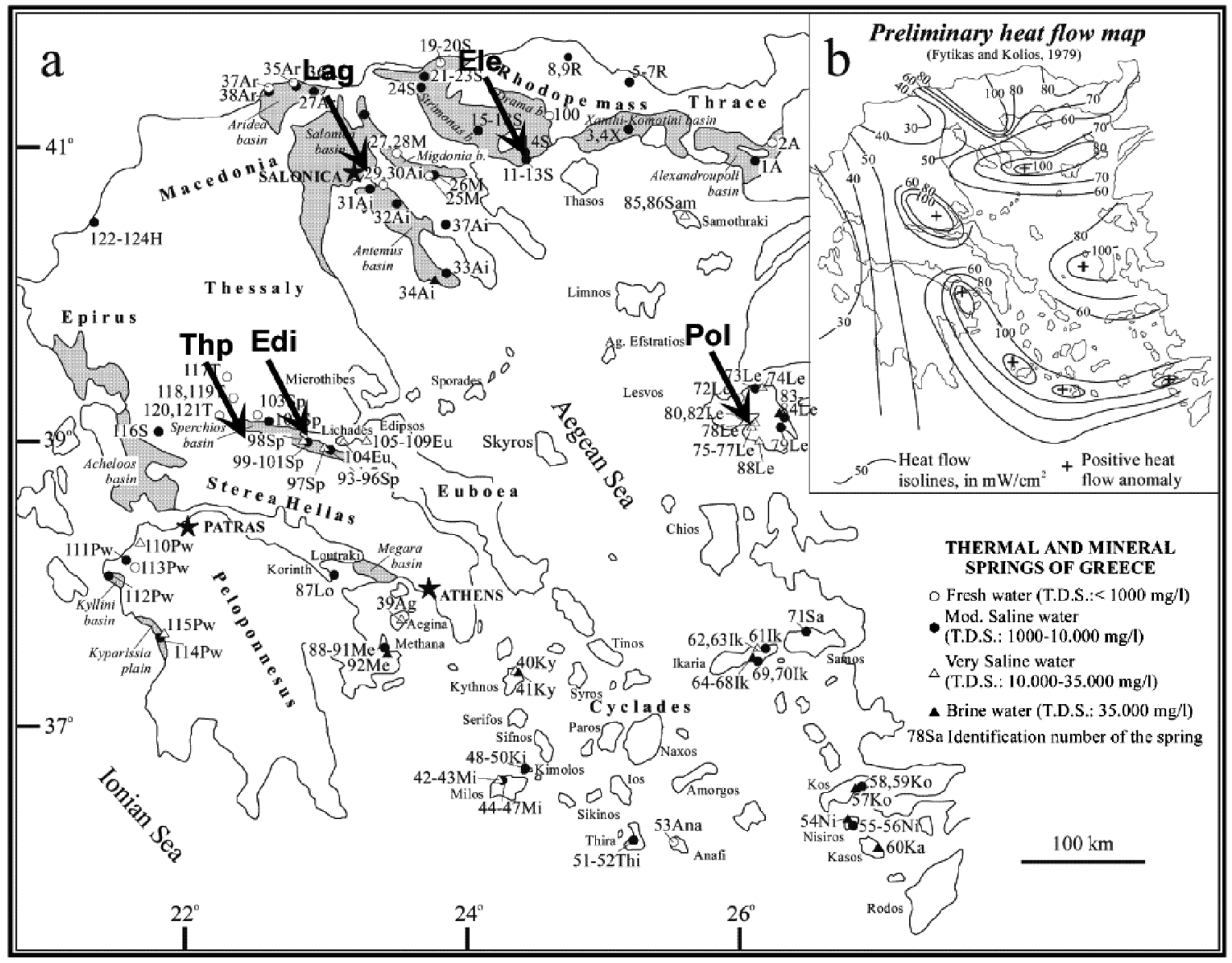

Fig. 1. Distribution map of the principal geothermal waters of Greece and location of the studied springs (arrows): Polihnitos (Pol), Edipsos (Edi), Eleftheres (Ele), Thermopiles (Thp) and Lagadas (Lag). For a full description of the map see Lambrakis \& Kallergis (2005)

clonal DNAs were amplified from randomly selected recombinants by direct PCR with M13 primers (M4, 5'GTT TTC CCA GTC ACG AC-3; RV, 5'-CAG GAA ACA GCT ATG AC-3'), purified with an HR column (MicroSpin S-400), and then used as templates for sequencing. Sequencing was performed with primers 907R (5'-CCG YCA ATT CMT TTR AGT TT-3'), a quick start kit (DTCS, Beckman), and an automated sequence analyzer (CEQ-2000, Beckman).

Phylogenetic and diversity analysis. Sequences of $\sim 500$ to $600 \mathrm{bp}$ from the same sample were compared with those in the DDBJ/EMBL/GenBank databases using the FASTA search programs (www.ddbj.nig.ac. jp/search/). Sequences with $\geq 98 \%$ similarity were grouped as identical operational taxonomic units (OTU). For unique OTUs, additional sequencing was performed with M4 and RV primers, and after contig construction of the whole amplified region, detection of chimeric DNAs using the CHECK-CHIMERA program (Maidak et al. 2001) of the Ribosomal Database Project was performed and all chimeric sequences were discarded. Sequences from the present study were assigned GenBank accession numbers EF444594 to EF444797.

The sequences were automatically aligned with their closest relatives data using the Clustal X program (Jeanmougin et al. 1998) and revised by manual removal of ambiguously aligned regions. Phylogenetic trees were constructed using the neighbor-joining method (Saitou \& Nei 1987) with the Clustal X program. Bootstrap analyses for 1000 replicates were performed to assign confidence levels to the tree topology by using PAUP $^{*}$ (phylogenetic analysis using parsimony) version 4.08b (Swofford 2000). Clone coverage was calculated using the equation $\mathrm{C}=\left[1 \times\left(n_{1} / N\right)\right] \times 100$, where $n_{1}$ is the number of single-occurrence OTUs and $N$ is the number of 16S rRNA sequences examined (Good 1953, Kemp \& Aller 2004). The Shannon-Wiener index $H^{\prime}$ was used as the diversity index and was calculated as follows: $H^{\prime}=\Sigma\left(p_{i}\right)\left(\log p_{i}\right)$, where the summation is over all OTUs, and $p_{i}$ is the proportion of OTU $i$ relative to the sum of all OTUs. The Shannon evenness index $E$ was calculated as $E=H^{\prime} / \mathrm{lnS}$, where $\mathrm{S}$ is the number of OTUs (Shannon \& Weaver 1949, Pielou 1969). 
Table 1. Sequences of oligonucleotide primers used for PCR amplifications. Pol: Polihnitos, Edi: Edipsos, Thp: Thermopiles, Ele: Eleftheres, Lag: Lagadas geothermal springs. $\mathrm{T}_{\mathrm{m}}$ : annealing temperature

\begin{tabular}{|c|c|c|}
\hline & Primer sequence $\left(5^{\prime}-3^{\prime}\right)$ & $\begin{array}{l}\text { Optimum } \\
\text { number of } \\
\text { cycles, } \\
\mathrm{T}_{\mathrm{m}}=50^{\circ} \mathrm{C}\end{array}$ \\
\hline \multicolumn{3}{|l|}{ Archaea } \\
\hline \multirow[t]{3}{*}{ Forward: Arc109f-mix ${ }^{a}$} & ACGGCTCAGTAACACGT & Pol: 30 \\
\hline & ACTGCTCAGTAACACGT & Edi: 38 \\
\hline & AAGGCTCAGTAACACGT & Thp: 32 \\
\hline \multirow[t]{2}{*}{ Reverse: Univ1492 $\mathrm{r}^{\mathrm{b}}$} & TACGGTTACCTTGTTACGACTT & Ele: 38 \\
\hline & TACGGCTACCTTGTTACGACTT & Lag: 35 \\
\hline \multicolumn{3}{|l|}{ Bacteria } \\
\hline \multirow[t]{4}{*}{ Forward: EUB338mix ${ }^{c}$} & ACTCCTACGGGAGGCAGC & Pol: 32 \\
\hline & ACTCCTACGGGAGGCTGC & Edi: 28 \\
\hline & ACACCTACGGGTGGCTGC & Thp: 22 \\
\hline & ACACCTACGGGTGGCAGC & Ele: 25 \\
\hline \multirow[t]{2}{*}{ Reverse: Univ1492 $\mathrm{r}^{\mathrm{b}}$} & TACGGTTACCTTGTTACGACTT & Lag: 26 \\
\hline & TACGGCTACCTTGTTACGACTT & \\
\hline \multicolumn{3}{|c|}{ a'Grosskopf et al. (1998), Kamagata et al. (unpubl.) } \\
\hline \multicolumn{3}{|c|}{ bane (1991) } \\
\hline \multicolumn{3}{|c|}{${ }^{\mathrm{C} A m a n n}$ et al. (1990), Daims et al. (1999) } \\
\hline
\end{tabular}

\section{RESULTS}

\section{Abiotic parameters and prokaryotic cell abundance}

The highest temperature $\left(89^{\circ} \mathrm{C}\right)$ was noted in Pol while the lowest was in Lag $\left(35.2^{\circ} \mathrm{C}\right)$ (Table 2$)$. The most acidic spring was Thp ( $\mathrm{pH} 5.14)$ while the rest of the springs were slightly acidic to neutral $(\mathrm{pH} 6.30$ to 6.98). Edi had the highest salinity (33 PSU) with the rest of the springs being either brackish (Thp 12.6, Pol 5.1 PSU) or fresh water (Ele, Lag). Lag was the only spring with oxygen saturated waters, followed by Thp with $37 \%$ and the rest of the springs with $\leq 12 \%$. Abundance of prokaryotic cells varied

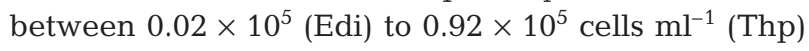
(Table 2).

Table 2. Abiotic parameters and prokaryotic cell abundance in Greek geothemal spring waters. PSU: practical salinity units

\begin{tabular}{|lccccc|}
\hline Spring & $\begin{array}{c}\text { Temp. } \\
\left({ }^{\circ} \mathrm{C}\right)\end{array}$ & $\mathrm{pH}$ & $\begin{array}{c}\text { Salinity } \\
(\mathrm{PSU})\end{array}$ & $\begin{array}{c}\text { Dissolved } \\
\text { oxygen } \\
\left(\mathrm{mg} \mathrm{l}^{-1}\right)\left[\mathrm{O}_{2}\right. \\
\text { saturation, } \%]\end{array}$ & $\begin{array}{c}\text { Prokaryotic } \\
\text { cell abundance } \\
(\text { cells ml }\end{array}$ \\
$\mathrm{SD})$
\end{tabular}

\section{Clone libraries analysis}

A total of 227 archaeal and 501 bacterial clones were analysed from the 5 geothermal springs, which belonged to 85 and 121 OTUs, respectively (Table S1, available as Supplementary material at www.int-res.com/suppl/ a057p113_app.pdf). Clone library coverage based on Good (1953) was at least $\sim 75 \%$, except for the archaeal clone libraries for Thp and Ele $(\sim 40$ and $60 \%$ respectively, Fig. 2), indicating that at least the most prevalent archaeal and bacterial groups in each clone library were identified.

\section{Phylogenetic and diversity analyses}

All results are shown in Table S1 and Figs. S1a-C, available as Supplementary material at www.int-res.com/ suppl/a057p113_app.pdf. In Pol, the archaeal community consisted of only 2 phylotypes. Thus, the low archaeal diversity was attributed to one Crenarchaeota phylotype (Pol-A-2, $93.9 \%$ dominance) related to tropical estuarine sediments, while the same spring showed the highest bacterial diversity of all the springs studied. The other phylotype (Pol-A-1) was closely related to Archaeoglobus fulgidus. The most abundant (17.1\%) bacterial phylotype (Pol-B-97) was related to environmental sequences derived from Taiwan hot springs and $\mathrm{Hy}_{\mathrm{y}}$ drogenophilus thermoluteolus. Other phylotypes were related to known thermophilic or uncultivated representatives of the phyla Chloroflexi, DeinococcusThermus, Bacteroidetes, Thermotogae, Aquificae, Planctomycetes and candidate division OP11.

In Edi, the dominant (43.2\%) archaeal phylotype (Edi-A-1) was the same as the dominant one in Pol. The rest of the archaeal phylotypes belonged to other Crenarchaeota (total $16.0 \%$ ) and Euryarchaeota $(41.0 \%)$ from similar systems or the deep subsurface. The dominant $(61.9 \%)$ bacterial phylotype (Edi-B-3) was related to Persephonella hydrogeniphila, while the rest of the phylotypes belonged to several phyla such as Nitrospirae, Proteobacteria (classes $\gamma$ and $\delta$ ), Cyanobacteria, Deferribacteres, Firmicutes, 'Termite group' and OP11, with representatives mostly from the deep subsurface and hot springs. 

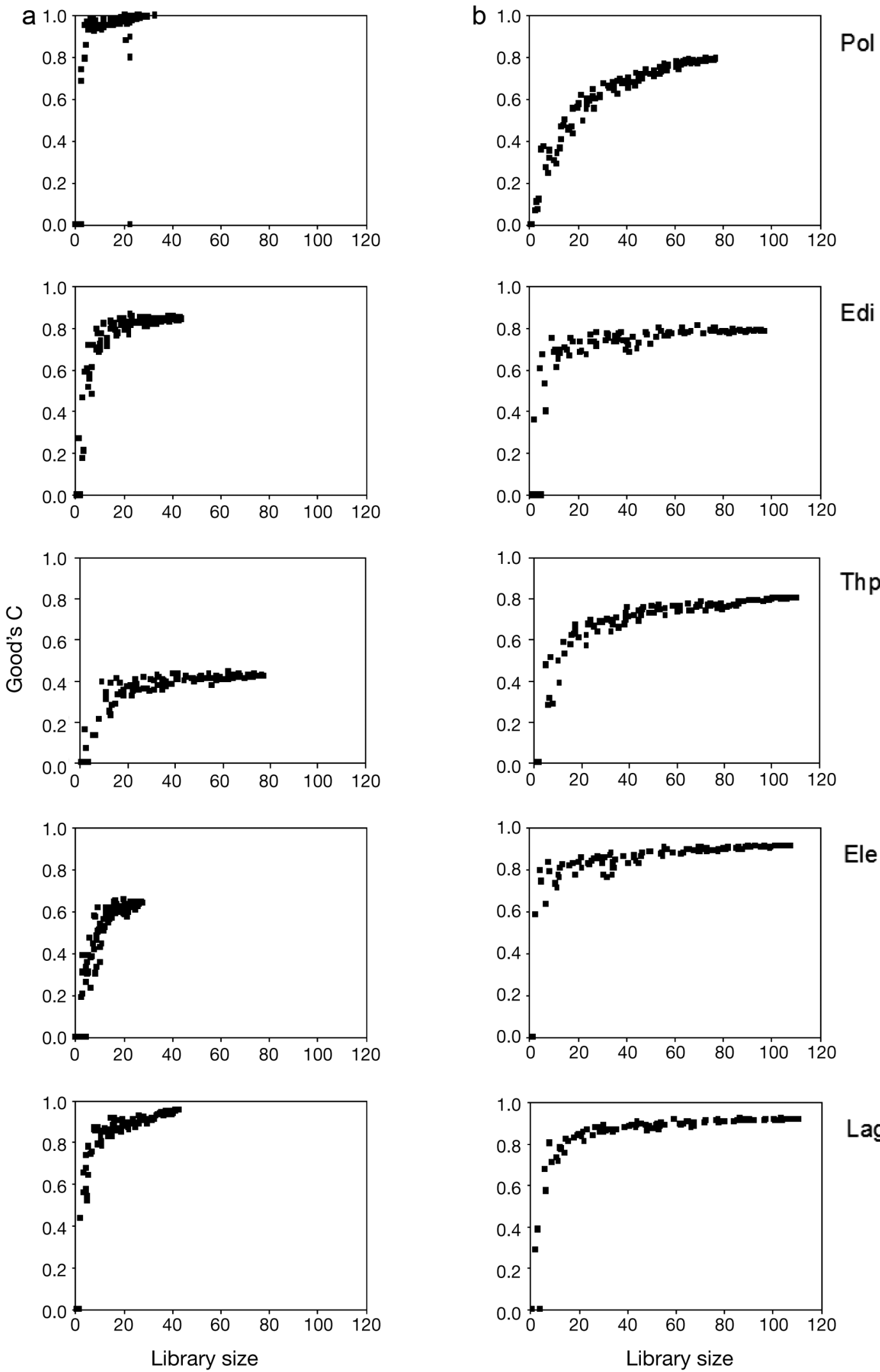

Fig. 2. Clone library coverage of (a) archaeal and (b) bacterial 16S rRNA genes (based on Good's C estimator) from the geothermal spring waters of Polihnitos (Pol), Edipsos (Edi), Thermopiles (Thp), Eleftheres (Ele) and Lagadas (Lag), Greece 
In Thp, the high archaeal diversity was attributed to the high number ( 47 or $61.1 \%$ of all phylotypes) of singleton phylotypes. The most dominant phylotype, Thp-A-14 (20.3\%), belonged to the Crenarchaeota and was related to a phylotype from a South African gold mine. Of all the archaeal phylotypes, only $6.5 \%$ belonged to the Euryarchaeota. The bacterial community in Thp was dominated by the $\gamma$-Proteobacteria $(>57.9 \%)$, with phylotype Thp-B-2 being the dominant one $(35.8 \%)$, which was related to a rhizosphere biofilm. The rest of the phylotypes belonged to the gamma, $\beta$-proteobacteria, OP11, Bacteroidetes, Thermotogae, Chlorobi, WS6, and Firmicutes, with their closest relatives originating from hot springs, anaerobic systems, hydrothermal vents and the subsurface.

In Ele, all archaeal phylotypes belonged to the Crenarchaeota. The 2 most abundant (25 and $17.9 \%$ ) phylotypes (Ele-A-22 and Ele-A-6, respectively), as well as the rest of the phylotypes, were related to phylotypes from deep subsurface environments. The low diversity of the Ele bacterial community was due to the high dominance $(72.2 \%)$ of phylotype Ele-B-1, which was related to a rhizosphere biofilm and belonged to the $\gamma$-Proteobacteria. This subphylum was also dominant in the rest of the phylotypes, followed by OP11 and Chloroflexi.

In Lag, the 2 dominant (46.5 and $34.9 \%$ ) phylotypes (Lag-A-2 and Lag-A-9, respectively) belonged to the Crenarchaeota and were related to soil phylotypes. All but one of the rest of the phylotypes also belonged to the Crenarchaeota and were related to phylotypes from subsurface anaerobic environments. The only Euryarchaeota phylotype (Lag-A-82) was related to deep-sea sediments.

The Shannon diversity index $H^{\prime}$ (Fig. 3) showed higher variation for Archaea (between 0.23 in Pol and 3.44 in Thp) than for Bacteria (between 1.22 in Ele and 3.03 in Pol). In Pol and Lag, archaeal was lower than bacterial diversity, with the former being higher in the rest of the springs. The Shannon evenness index $E$ varied between 0.33 and 0.88 for Archaea and 0.44 and 0.89 for Bacteria, and was higher for Bacteria only in Pol (Fig. 3).

All clone libraries contained rare phylotypes (sensu Aller \& Kemp 2008, Fig. 4). Archaeal and bacterial libraries respectively contained 50 to 94.1 and 68.8 to $96.2 \%$ rare phylotypes. A positive relationship was observed between the number of rare and observed phylotypes, for both archaeal $(\mathrm{p}<0.01)$ and bacterial $(\mathrm{p}$ $<0.02$ ) clone libraries. There was a significant relationship between library size and the number of rare phylotypes (positive linear regression slope $=0.87, \mathrm{r}^{2}=$ $82.5 \%, \mathrm{p}<0.01)$ but only for the archaeal clone libraries.
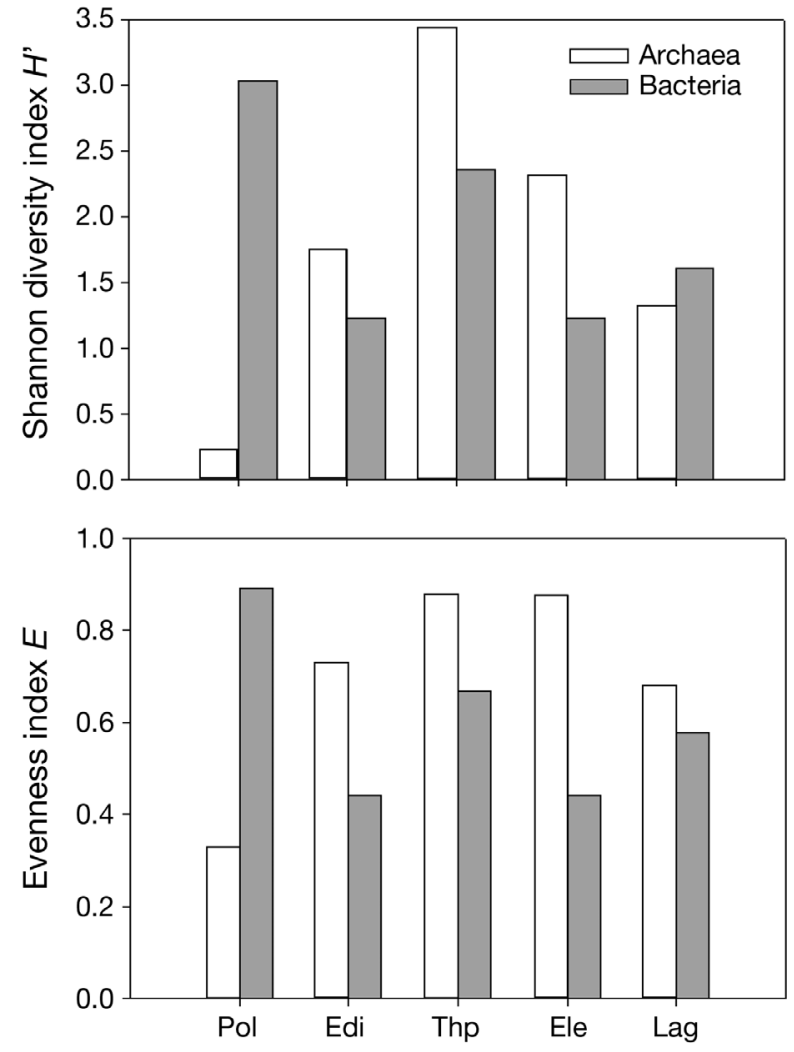

Fig. 3. Shannon diversity $\left(H^{\prime}\right)$ and evenness $(E)$ indices for the bacterial and archaeal 16S rRNA gene clone libraries, from the geothermal spring waters of Polihnitos (Pol), Edipsos (Edi), Thermopiles (Thp), Eleftheres (Ele) and Lagadas (Lag), Greece

\section{DISCUSSION}

Our experimental approach targeted on revealing the largest extent of the prokaryotic 16S rRNA genetic diversity in 5 geothermal springs in Greece, with temperatures ranging from 36 to $89^{\circ} \mathrm{C}$. This was achieved by (1) using primer mixtures at low annealing temperature $\left(50^{\circ} \mathrm{C}\right)$ to avoid any mismatches that could exclude some microorganisms (Sipos et al. 2007), (2) PCR cycle optimization in order to eliminate innate PCR artifacts (v. Wintzingerode et al. 1997) and reduce relative differences in abundance between the more abundant and rarer OTUs, and (3) examining the clone library coverage of each library before closing the library, without the limitation of a pre-determined minimum clone number to be analysed. Kemp \& Aller (2004) have already stressed the scarcity of high clone coverage studies and the importance of knowing the full extent of diversity in environmental clone libraries for a better understanding of the role of diversity in the functioning of the ecosystem. The Shannon diversity index $H^{\prime}$ causes overestimation in samples with low 

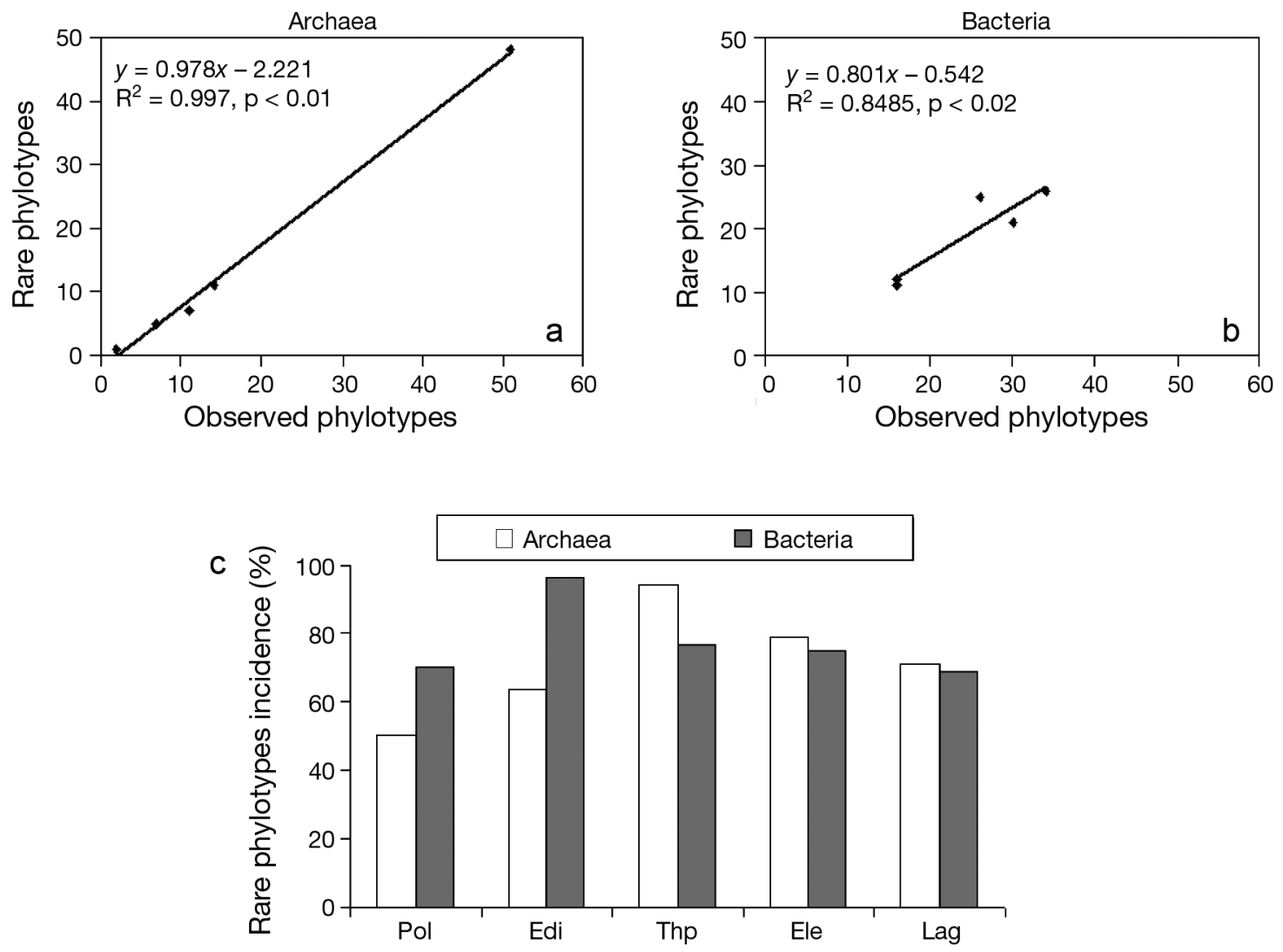

Fig. 4. Comparison of the number of rare phylotypes (i.e. those which occur only once or twice in a clone library) to the total number observed in all (a) archaeal and (b) bacterial libraries. Libraries which fall below the 1:1 line tend to have uniformly abundant phylotypes, while libraries above the line have a skewed distribution with many rare phylotypes. (c) \% Contribution of rare phylotypes in each of the clone libraries from the geothermal spring waters of Polihnitos (Pol), Edipsos (Edi), Thermopiles (Thp), Eleftheres (Ele) and Lagadas (Lag), Greece

coverage (Hill et al. 2003). Our satisfactory clone library coverage allowed us to reveal the 'vast' majority of the existing prokaryotic diversity in most of the studied springs, albeit to a lesser degree for the Archaea in Thp and Ele, making the Shannon diversity index $H^{\prime}$ applicable and realistically informative.

The prokaryotic cell abundance was low compared with other geothermal springs (Kimura et al. 2005, Belkova et al. 2007, Hetzer et al. 2007, Mathur et al. 2007) but comparable with values from geothermal subsurface environments (Schulze-Makuch \& Kennedy 2000, Kieft et al. 2005). The lack of correlation of cell abundance with temperature, $\mathrm{pH}$, salinity and dissolved oxygen content (data not shown), suggests that the observed low cell numbers are controlled by other factors, such as the availability of electron acceptors and/or viral infection (Lee et al. 2007).

It is known that Crenarchaeota dominate in geothermal springs (Barns et al. 1994, Huang et al. 2007). In the present study, only 10 of the 85 archaeal OTUs belonged to the Euryarchaeota, while one spring (Ele) had no euryarchaeotal phylotypes. In addition, most of the discovered Euryarchaeota phylotypes were not abundant in the clone libraries where they came from, except for Edi-A-46 which represented $18.2 \%$ of all existing archaeal phylotypes in this specific library. The dominance of the Crenarchaeota is not so surprising since, at least in terms of cultured representatives, practically all members of this group are thermophiles; in contrast, Euryarchaeota are more diverse both in metabolism and habitats, and include mesophilic, thermophilic, and hyperthermophilic organisms as well as extreme halophiles in terms of temperature tolerance. The possibility that Crenarchaeota and Euryarchaeota possess different ecological niches (i.e. spatial or temporal dominance of the former or latter) in the same ecosystems has also been suggested for planktonic communities in Antarctic regions (Massana et al. 1988, Murray et al. 1998), in the deep Atlantic Ocean (Herndl et al. 2005), the North Sea (Herfort et al. 2007) and deep hypersaline anoxic basins (van der Wielen et al. 2005). In Yellowstone geothermal springs (Barns et al. 1994, 1996) and in the hot, reducing, and iron and zinc sulfide-rich interior regions of a deep-sea 
hydrothermal vent black smoker chimney, the Crenarchaeota dominated the whole prokaryotic community (Takai et al. 2001, Schrenk et al. 2003); however, the Euryarchaeota dominated in a white smoker spire in the East Pacific Rise $\left(9^{\circ} \mathrm{N}\right.$, Kormas et al. 2006) and in a geothermal aquifer (Kimura et al. 2005). Nevertheless, the actual relative abundance of Crenarchaeota and Euryarchaeota in Greek geothermal springs remains to be confirmed, preferably using fluorescence in situ hybridization (FISH).

In the present study, the physiological features of the discovered Crenarchaeota OTUs cannot be inferred with great confidence since most of them were related to phylotypes of yet-uncultivated species. In addition, physiologic traits are not necessarily always coherent within phylogenetic groups. However, these environmental sequences originated from hydrothermal, geothermal, or anaerobic environments suggesting that the discovered phylotypes could represent indigenous thermophilic organisms of the geothermal springs. Such uncultivated thermophilic Crenarchaeota are abundant in geothermal areas which are rich in hydrogen, $\mathrm{Fe}(\mathrm{II})$ and sulfur at many oxidation states, and may also be chemolithotrophic. Overall, the majority of the Archaea we found are possible members of an indigenous hot subsurface community except for those in Lag, Lag being a shallow spring with upcoming water that is mixed with meteoric water (Traganso et al. 1995). This spring is more susceptible to 'contamination' from soil microorganisms, which are similar to its several soil-related Archaea phylotypes, while its low temperature may inhibit or eliminate thermophilic microorganisms coming from the deep subsurface. Finally, it is possible that there is a higher variety of substrates originating from the more physically and chemically complex nature of soil in Lag.

The finding of nonthermophilic Crenarchaeota in warm and hot environments is becoming increasingly common (Jurgens et al. 1997, Kanokratana et al. 2004, Kvist et al. 2005, 2007, Huang et al. 2007). We also found several such OTUs that are especially related to tropical estuarine sediments and fresh water. Kvist et al. (2005) suggested that DNA from nonthermophilic Archaea is not amplifiable; thus, the phylotypes found in such clone libraries represent Archaea that may also tolerate or even grow at higher temperatures. Considering our stringent PCR protocols and the large enough clone libraries, we believe that the nonthermophilic OTUs we have found could also be thermophilic.

Unlike the archaeal phylotypes, several of the bacterial phylotypes were related to described bacterial species. The dominance of phylotypes related to thermophilic phylogenetic groups and/or environmental sequences retrieved from habitats with moderate to high temperatures falls from at least 68.2 and $78.5 \%$ for Pol and Edi, respectively, to 35.6, 14.7 and $1.8 \%$ for Thp, Ele and Lag, respectively. As most of the studied springs are subject to the mixing of geothermal fluids with meteoric waters at some point in their fluid ascension (Lambrakis \& Kallergis 2005, Duriez et al. 2008), it is believed that microorganisms originating from cooler environments will have less chances of surviving in the waters of those springs with the highest temperatures, like Pol and Edi, unless they have protective adaptations, like spore formation (e.g. Baker et al. 2001). Geothermometer calculations (Lambrakis \& Kallergis 2005) suggested that the temperature of the deep subsurface waters of the studied springs are $142-180,109-152,124-164,218-241$ and $131-171^{\circ} \mathrm{C}$ for Pol, Edi, Thp, Ele and Lag, respectively. Based on the measured surface temperatures in the present study, Pol and Edi showed the lowest difference between the temperatures of deep and surface waters (53 to 91 and 27 to $70^{\circ} \mathrm{C}$, respectively). Such small differences between deep subsurface and surface waters imply either a faster flow (i.e. less chances for contamination from non-subsurface microorganisms) and/or less mixing with meteoric water. This renders the Pol and Edi springs more likely of hosting an indigenous hot subsurface community. Indeed, only in Pol and Edi are the most abundant phylotypes closely related to the thermophilic microorganisms Hydrogenophilus thermoluteolus and Persephonella hydrogeniphila, respectively; in the rest of the springs, mixtures of thermophiles and mesophiles prevail. Pol and Edi also had the highest $\mathrm{G}+\mathrm{C}$ contents $(60.1$ and $55.7 \%$, respectively; Fig. 5). It is known that the G+C content of $16 \mathrm{~S}$ rRNAs is positively correlated with $T_{\mathrm{opt}}$ for bacterial species (Galtier \& Lobry 1997). Within the same springs, the archaeal 16S rRNAs also had the highest $\mathrm{G}+\mathrm{C}$ contents (60.2 and $58.1 \%$, respectively).

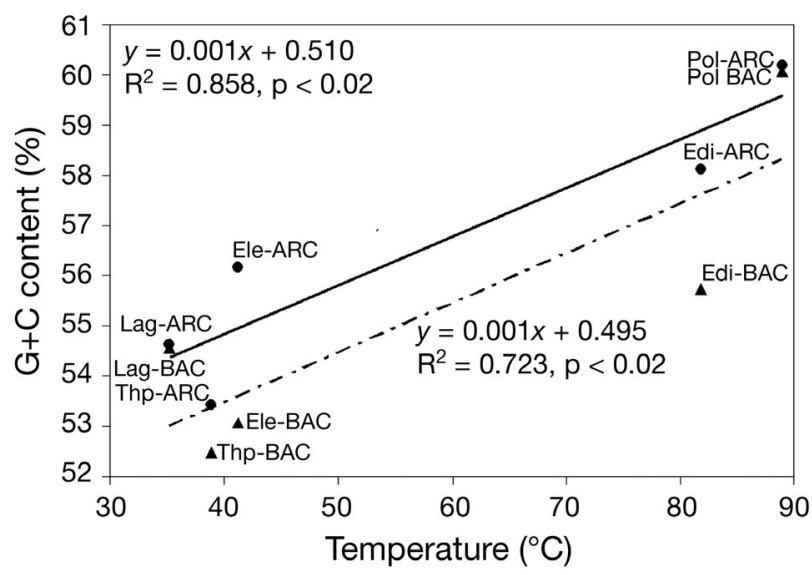

Fig. 5. Relationship of the $\mathrm{G}+\mathrm{C}$ content of the retrieved bacterial (BAC) $(-\cdot-\cdot-)$ and archaeal (ARC) (-) 16S rRNA gene sequences with the prevailing temperature in the geothermal spring waters of Polihnitos (Pol), Edipsos (Edi), Eleftheres (Ele), Thermopiles (Thp) and Lagadas (Lag), Greece 
Members of the $\gamma$-Proteobacteria dominate in sulfidic and marine environments and are mostly involved in ecosystem function via chemolithoautotrophic metabolic pathways (Campbell et al. 2006). Recently, the first nonmarine natural system where this group dominates has been reported (Porter \& Engel 2008). Here we also report their dominance in a freshwater geothermal spring (Ele) and additionally, their dominance in a brackish spring (Thp), thus supporting the cosmopolitan distribution of this group.

The importance of phylogenetically rare prokaryotic phylotypes in environmental samples has been recently highlighted (Sogin et al. 2006, Aller \& Kemp 2008). The occurrence of rare phylotypes in all of our investigated archaeal and bacterial clone libraries started at $50 \%$ and reached $96.2 \%$. Such high numbers of rare phylotypes indicate the high species richness of the systems where they are found. It has been suggested that in microbial populations, rare species can possess a survival advantage by directly competing with the dominant ones (Sogin et al. 2006). For the Archaea in the geothermal springs studied here, we suggest that rare phylotypes play a more central role in enhancing phylogenetic diversity as revealed by the linear relationship between the number of rare of phylotypes and library size.

In conclusion, the apparent richness and community composition of Bacteria and Archaea in the studied geothermal springs showed different patterns. Diversity was unrelated to the prevailing temperature, $\mathrm{pH}$, salinity and dissolved oxygen concentrations. The inferred ecophysiology of at least the dominant phylotypes, coupled with geothermometer estimations, suggests that at least for the 2 hottest springs, an indigenous deep and hot subsurface community reaches the surface. In all other springs, microbial contamination due to the mixing of geothermal water with meteoric water, shapes different prokaryotic communites in terms of species richness and diversity.

Acknowledgements. We thank M. Miroshnichenko for critical reading of the manuscript. Part of this work was supported by a scholarship to K.A.K. from the Matsumae International Foundation, Japan.

\section{LITERATURE CITED}

Aller JY, Kemp PF (2008) Are Archaea inherently less diverse than Bacteria in the same environments? FEMS Microbiol Ecol 65:74-87

Amann RI, Binder BJ, Olson RJ, Chisholm SW, Devereux R, Stahl DA (1990) Combination of 16s rRNA-targeted oligonucleotide probes with flow cytometry for analyzing mixed microbial populations. Appl Environ Microbiol 56:1919-1925
Baker GC, Gaffar S, Cowan DA, Suharto AR (2001) Bacterial community analysis of Indonesian hot springs. FEMS Microbiol Lett 200:103-109

Barns SM, Eundyga RE, Jeffries MW, Pace NR (1994) Remarkable archaeal diversity detected in a Yellowstone National Park hot spring environment. Proc Natl Acad Sci USA 91:1609-1613

Barns SM, Delwiche CF, Palmer JD, Pace NR (1996) Perspectives on archaeal diversity, thermophily and monophyly from environmental rRNA sequences. Proc Natl Acad Sci USA 93:9188-9193

- Belkova NL, Tazaki K, Zakharova JR, Parfenova VV (2007) Activity of bacteria in water of hot springs from southern and central Kamchatskaya geothermal provinces, Kamchatka Peninsula, Russia. Microbiol Res 162:99-107

Campbell BJ, Engel AS, Porter ML, Takai K (2006) The versatile $\varepsilon$-proteobacteria: key players in the sulphur cycle. Nat Rev Microbiol 4:458-468

Daims H, Bruhl A, Amann R, Schleifer KH, Wagner M (1999) The domain-specific probe EUB338 is insufficient for the detection of all Bacteria: development and evaluation of a more comprehensive probe set. Syst Appl Microbiol 22:434-444

- Duriez A, Marlin C, Dotsika E, Massault M, Noret A, Morel JL (2008) Geochemical evidence of seawater intrusion into a coastal geothermal field of central Greece: example of the Thermopylae system. Environ Geol (Berl) 54:551-564

> Galtier N, Lobry JR (1997) Relationships between genomic G+C content, RNA secondary structures, and optimal growth temperature in prokaryotes. J Mol Evol 44: 632-636

Good IJ (1953) The population frequencies of species and the estimation of population parameters. Biometrika 43:45-63

- Grosskopf R, Janssen PH, Liesack W (1998) Diversity and structure of the methanogenic community in anoxic rice paddy soil microcosms as examined by cultivation and direct 16S rRNA gene sequence retrieval. Appl Environ Microbiol 64:960-969

Herfort L, Schouten S, Abbas B, Veldhuis MJW and others (2007) Variations in spatial and temporal distribution of Archaea in the North Sea in relation to environmental variables. FEMS Microbiol Ecol 62:242-257

> Herndl GJ, Reinthaler T, Teira E, van Aken H, Eth C, Pernthaler A, Pernthaler J (2005) Contribution of Archaea to total prokaryotic production in the deep Atlantic Ocean. Appl Environ Microbiol 71:2303-2309

> Hetzer A, Morgan HW, McDonald IR, Daughney CJ (2007) Microbial life in Champagne Pool, a geothermal spring in Waiotapu, New Zealand. Extremophiles 11:605-614

> Hill TCJ, Walsh KA, Harris JA, Moffett BF (2003) Using ecological diversity measures with bacterial communities. FEMS Microbiol Ecol 43:1-11

Huang Z, Hedlund BP, Wiegel J, Zhou J, Zhang ZL (2007) Molecular phylogeny of uncultivated Crenarchaeota in Great Basin hot springs of moderately elevated temperature. Geomicrobiol J 24:535-542

Jeanmougin F, Thompson JD, Gouy M, Higgins DG, Gibson TJ (1998) Multiple sequence alignment with Clustal X. Trends Biochem Sci 23:403-405

Jurgens G, Lindstrom K, Saano A (1997) Novel group within the Kingdom Crenarchaeota from boreal forest soil. Appl Environ Microbiol 63:803-805

Kanokratana P, Chanapan S, Pootanakit K, Eurwilaichitr L (2004) Diversity and abundance of Bacteria and Archaea in the Bor Khlueng hot spring in Thailand. J Basic Microbiol 44:430-444

Kemp PF, Aller JY (2004) Estimating prokaryotic diversity: When are 16S rDNA libraries large enough? Limnol Oceanogr Methods 2:114-125 
Kieft TL, McCuddy SM, Onstott TC, Davidson M and others (2005) Geochemically generated, energy-rich substrates and indigenous microorganisms in deep, ancient groundwater. Geomicrobiol J 22:325-335

Kimura H, Sugihara M, Yamamoto H, Patel BKC, Kato K, Hanada S (2005) Microbial community in a geothermal aquifer associated with the subsurface of the Great Artesian Basin, Australia. Extremophiles 9:407-414

Kormas KA, Tivey MK, von Damm K, Teske A (2006) Bacterial and archaeal phylotypes associated with distinct mineralogical layers of a white smoker spire from a deep-sea hydrothermal vent site $\left(9^{\circ} \mathrm{N}\right.$, East Pacific Rise). Environ Microbiol 8:909-920

Kvist T, Mengewein A, Manzei S, Ahring BK, Westermann P (2005) Diversity of thermophilic and non-thermophilic crenarchaeota at $80^{\circ} \mathrm{C}$. FEMS Microbiol Lett 244:61-68

Kvist T, Ahring BK, Westermann P (2007) Archaeal diversity in Icelandic hot springs. FEMS Microbiol Ecol 59:71-80

Lambrakis N, Kallergis G (2005) Contribution to the study of Greek thermal springs: hydrogeological and hydrochemical characteristics and origin of thermal waters. Hydrogeol J 13:506-521

Lee MH, Keams JL, Hezler DW, Leiser OP and others (2007) Evaluation of viral and prokaryotic community dynamics in Alvord Desert hot springs, Oregon, USA. Aquat Microb Ecol 48:19-26

Maidak BL, Cole JR, Lilburn TG, Parker CT Jr and others (2001) The RDP-II (Ribosomal Database Project). Nucleic Acids Res 29:173-174

Massana R, Taylor LT, Murray AE, Wu KY, Jeffery WH, DeLong EF (1988) Vertical distribution and temporal variation of marine planktonic archaea in the Gerlache Strait, Antarctica, during early spring. Limnol Oceanogr 43: 607-617

Mathur J, Bizzoco RW, Ellis DG, Lipson DA, Poole AW, Levine R, Kelley ST (2007) Effects of abiotic factors on the phylogenetic diversity of bacterial communities in acidic thermal springs. Appl Environ Microbiol 73:2612-2623

Meintanis C, Chalkou K, Kormas KA, Karagouni A (2006) Biodegradation of crude oil by thermophilic bacteria isolated from a volcano island. Biodegradation 17:3-9

> Murray AE, Preston CM, Massana R, Taylor LT, Blaski A, Wu K, DeLong EF (1998) Seasonal and spatial variability of bacterial and archaeal assemblages in the coastal waters near Anvers Island, Antarctica. Appl Environ Microbiol 64:2585-2595

Pielou EC (1969) An introduction to mathematical ecology. Wiley, New York

> Porter ML, Engel AS (2008) Diversity of uncultured Epsilonproteobacteria from terrestrial sulfidic caves and springs. Appl Environ Microbiol 74:4973-4977

Saitou N, Nei M (1987) The neighbor-joining method: a new method for reconstructing phylogenetic trees. Mol Biol Evol 4:406-425

Editorial responsibility: Gerhard Herndl, Vienna, Austria
Schrenk MO, Kelley DS, Delaney JR, Baross JA (2003) Incidence and diversity of microorganisms within the walls of an active deep-sea sulfide chimney. Appl Environ Microbiol 69:3580-3592

Schulze-Makuch D, Kennedy JF (2000) Microbiological and chemical characterization of hydrothermal fluids at Tortugas Geothermal Area, southern New Mexico, USA. Hydrogeol J 8:295-309

Shannon CE, Weaver W (1949) The mathematical theory of communication. University of Illinois Press, Urbana

> Sievert SM, Brinkhoff T, Muyzer G, Ziebis W, Kuever J (1999) Spatial heterogeneity of bacterial populations along an environmental gradient at a shallow submarine hydrothermal vent near Milos Island (Greece). Appl Environ Microbiol 65:3834-3842

> Sievert SM, Ziebis W, Kuever J, Sahm K (2000) Relative abundance of Archaea and Bacteria along a thermal gradient of a shallow-water hydrothermal vent quantified by rRNA slot-blot hybridization. Microbiology 146:1287-1293

> Sipos R, Székely AJ, Palatinszky M, Rèvèsz S, Márialigety K, Nikolausz M (2007) Effect of primer mismatch, annealing temperature and PCR cycle number on 16S rRNA genetargetting bacterial community analysis. FEMS Microbiol Ecol 60:341-350

Sogin ML, Morrison HG, Huber JA, Welch DM and others (2006) Microbial diversity in the deep sea and the underexplored 'rare biosphere'. Proc Natl Acad Sci USA 103: 12115-12120

Staley JT, Resenbach AL (2002) Biodiversity of microbial life. Foundation of earth's biosphere. Wiley-Liss, New York

Swofford DL (2000) PAUP*. Phylogenetic analysis using parsimony (and other methods), Version 4, CD-ROM. Sinauer Associates, Sunderland, MA

Takai K, Komatsu T, Inagaki F, Horikoshi K (2001) Distribution of Archaea in a black smoker chimney structure. Appl Environ Microbiol 67:3618-3629

- Traganso G, Jux U, Steuber T (1995) Isotopic characteristics of geothermal waters and fossil spring deposits in Mygdonia Basin, northern Greece. Geothermics 24:61-80

Turley CM (1993) Direct estimates of bacterial numbers in seawater samples without incurring cell loss due to sample storage. In: Kemp PF, Sherr BF, Sherr EB, Cole JJ (eds) Handbook of methods in aquatic microbial ecology. Lewis Publishers, Boca Raton, FL, pp 143-148

v. Wintzingerode F, Göbel UB, Stackebrandt E (1997) Determination of microbial diversity in environmental samples: pitfalls of PCR-based rRNA analysis. FEMS Microbiol Rev 21:213-229

van der Gast CJ (2008) Islands shaping thought in microbial ecology. Adv Appl Microbiol 64:167-182

van der Wielen PWJJ, Bolhuis H, Borin S, Daffonchio D and others (2005) The enigma of prokaryotic life in deep hypersaline anoxic basins. Science 307:121-123

Submitted: January 15, 2009; Accepted: June 4, 2009

Proofs received from author(s): September 1, 2009 